\title{
Biomarkers in Liver Disease: From Diagnosis to Prognosis
}

\author{
Heba F. Pasha \\ Medical Biochemistry Department, Faculty of Medicine, Zagazig University, Zagazig, \\ Egypt
}

Corresponding Author Heba F. Pasha

\section{Mobile:002010057880 30}

\section{E mail:}

hebapasha@yahoo.co $m$

Key words: Liver Disease;miR122; Presepsin; Resistin

\section{INTRODUCTION}

Hepatitis $\mathrm{C}$ is a global health problem which can trigger a chronic inflammatory disease process that might lead to liver fibrosis, cirrhosis and even hepatocellular carcinoma [1]. Patients with cirrhosis can be asymptomatic or symptomatic, depending on whether their cirrhosis is clinically compensated or decompensated. In compensated cirrhosis, patients are usually asymptomatic. On the other hand, patients with decompensated cirrhosis usually present with a wide range of signs and symptoms arising from a combination of liver dysfunction and portal hypertension. Multiple organs are affected with gastrointestinal, renal, pulmonary, cardiological and endocrine manifestations [2].

Furthermore, bacterial infections can occur in nearly one quarter of hospitalized decompensated cirrhotic patients [3] which trigger inflammatory response that causes progression of liver failure and development of complications; hence increases morbidity and mortality [4]. Consequently, early diagnosis of chronic viral hepatitis and as well as early detection of superadded bacterial infections may play an important role in hepatitis treatment, inhibits disease progression, and reduces morbidity and mortality.

Increasing evidence suggests that miRNAs are essential for the regulation of liver development, regeneration and metabolic functions [5]. Hence, alterations in intrahepatic miRNA networks have been associated with all aspects of liver disease, including hepatitis, cirrhosis and HCC [6]. miR-122 is the most frequent miRNA in the adult liver $[7,8]$. Interestingly, miR-122 can be detected in the circulation and serum miR-122 has been shown to serve as a biomarker of liver injury including chronic hepatitis B or C [9-11].

miR-122 has a liver-enriched expression and is one of the most abundant miRNAs in the liver, accounting for about $52 \%$ of the whole hepatic miRNome in adult human [7].

A study published in Afro-Egypt $\mathrm{J}$ Infect Endem Dis under the title of "Serum MiRNA-122 as a Diagnostic Marker in HCV Related Liver Cirrhosis" aimed to evaluate serum miRNA-122 expression as a potential biomarker for diagnosis and monitoring different stages of disease in chronic hepatitis $\mathrm{C}$ patients.

The study revealed that miRNA-122 expression levels were significantly increased among liver disease patients than healthy controls. Furthermore, miRNA-122 expression levels were significantly higher in the compensated patients compared to the decompensated patients. Also, this study elucidated that serum miRNA122 levels were decreased with the progression of liver disease (from Child-Pugh class A to C) but without reaching to a significant difference .

Additionally, patients with ascites had a significantly lower expression of miR-122 compared to those without ascites, while patients with gastrointestinal bleeding and hepatic encephalopathy had statistically 
insignificant lower expression of miRNA 122 compared to subjects without these complications. A significant positive correlation between miRNA-122 expression and (AST, ALT, albumin, and viral load) were detected as well as a significant negative correlation as regard INR .

Collectively, the study figured out the role of serum miRNA-122 expression in the progression of liver disease and its potential usage as a new diagnostic marker in hepatitis $\mathrm{C}$ patients with different stages of the disease.

Infected patients with cirrhosis can be asymptomatic at initial stages, but highly susceptible to dissemination of infections due to their immunocompromised state that often leads to development of severe disease specific complications with significant mortality rate[12,13]. Therefore, early recognition of bacterial infections is essential, however, in the clinical practice their accurate identification is challenging from both the clinical[14] and the laboratory point of view[15]. Currently C $\neg$ reactive protein (CRP) and procalcitonin (PCT) are broadly used in the clinical practice to aid the early diagnosis of bacterial infection[16]. Consequently, finding out accurate laboratory markers is a must to maximize the efficacy of diagnostic procedure of bacterial infections and thus making early intervention possible.

Presepsin (soluble CD14 subtype, sCD14ᄀST) is a $13 \neg \mathrm{kD}$ a cleavage product of $\mathrm{CD} 14$ receptor that recognizes different cell surface structure of both Gram-negative and positive bacteria. Presepsin in the circulation can be perceived as a witness of activated monocyte-macrophage in response to pathogens[17]. Several recent clinical studies have shown that presepsin is a specific and sensitive novel marker for the diagnosis of sepsis [18], for evaluating the severity of sepsis and for predicting the outcome[19,20]. Beyond sepsis, presepsin is worthy of studying in those clinical settings, where systemic infections are frequently associated with severe diseases course such in cirrhosis [acute decompensation (AD), organ failure]. Contributive role of presepsin for the diagnosis and prognosis of cirrhosis associated bacterial infection has not been assessed extensively so far.

Resistin, an insulin resistance-modulating hormone, is secreted by adipocytes and macrophages. It has a novel proinflammatory function that enhances the neutrophil response to
LPS stimulation. Elevated serum levels of resistin were detected in severe sepsis and septic shock [21-22]. Besides, in liver cirrhosis, resistin positively correlates with disease stage, and negatively correlates with survival [23].

According to an interesting study published in the current issue of the Afro-Egyptian Journal of Infectious and Endemic Disease " Presepsin and Resistin as Diagnostic Markers for Bacterial Infection in Patients with Decompensated Cirrhosis"Presepsin and resistin were significantly higher among patients with infection and positively correlated with Model for Endstage Liver Disease score (MELD), Child-pough score (CPS), CRP and PCT. At $1205 \mathrm{pg} / \mathrm{ml}$ as cutoff, Presepsin could predict infection at sensitivity $83.8 \%$, specificity $93 \%$ and accuracy $88.7 \%$. While using $21 \mathrm{ng} / \mathrm{ml}$ as cutoff, Resistin could predict infection at sensitivity $64.6 \%$, specificity $68.4 \%$ and accuracy $66.7 \%$. Adding CRP to PCT or presepsin increased sensitivity to 99\%, specificity $73.7 \%$, and accuracy $85.4 \%$. Adding presepsin to PCT or resistin increased sensitivity to $94.9 \%$. Yet combined presepsin and PCT had higher specificity than combined presepsin and resistin. Conclusion: Presepsin has comparable diagnostic performances to CRP and PCT for bacterial infection in decompensated cirrhosis while resistin has poor sensitivity and specificity. Adding presepsin to CRP yields the same diagnostic performance as combined CRP and PCT. So, combining any of them to CRP helps to early diagnose bacterial infection in those patients.

Finally, serum miRNA-122 seems to be a useful new diagnostic marker in hepatitis $\mathrm{C}$ patients with different stages of the disease. Furthermore, the present study suggests that presepsin is a promising biomarker during diagnostic procedure of bacterial infections in cirrhosis by enhancing the diagnostic capacity of CRP and reflecting more accurately the severity of infections. The main limitation of these studies is being carried in a single center with a relatively small sample size consequently further studies are needed in large scale to establish these findings

\section{REFERENCES}

1. Wei L, Lok AS. Impact of new hepatitis C treatments in different regions of the world.Gastroenterology 2014; 146:1145-50. 
2. Naveau S, Perlemuter G, Balian A. Epidemiology and natural history of cirrhosis. Rev Prat. 2005 30; 55(14):1527-32.

3. Fernández J, Gustot T. Management of bacterial infections in cirrhosis. J Hepatol 2012; 56(Suppl 1):S1-12.

4. Jalan R, Fernandez J, Wiest R, Schnabl B, Moreau $\mathrm{R}$, Angeli $\mathrm{P}$, et al. Bacterial infections in cirrhosis: a position statement based on the EASL Special Conference 2013. J Hepatol 2014; 60: 1310-1324

5. Chen Y, Verfaillie CM. MicroRNAs: the fine modulators of liver development and function.Liver Int, 34 (2014), pp. 976-990

6. Szabo G, Bala S. MicroRNAs in liver disease.Nat Rev Gastroenterol Hepatol2013; 10: 542-552

7. Girard M, Jacquemin E, Munnich A, Lyonnet S, Henrion-Caude A.MiR-122, paradigm for the role of microRNAs in the liver.J Hepatol 2008; 48: 648-656

8. Hou W, Tian Q, Zheng J, Bonkovsky HL. MicroRNA-196 represses Bach1 protein and hepatitis $\mathrm{C}$ virus gene expression in human hepatoma cells expressing hepatitis $\mathrm{C}$ viral proteins.Hepatology2010; 51: 1494-1504

9. Waidmann O, Bihrer V, Pleli T, Farnik H, Berger A, Zeuzem S, et al. Serum microRNA-122 levels in different groups of patients with chronic hepatitis B virus infection.J Viral Hepat2012; 19: e58-e65

10. Van der Meer AJ, Farid WRR, Sonneveld MJ, de Ruiter P, Boonstra A, van Vuuren A, et al.Sensitive detection of hepatocellular injury in chronic hepatitis $\mathrm{C}$ patients with circulating hepatocyte-derived microRNA-122.J Viral Hepat 2013; 20: 158-166

11. Köberle V, Waidmann O, Kronenberger B, Andrei A, Susser S, Füller C, et al. Serum microRNA122 kinetics in patients with chronic hepatitis C virus infection during antiviral therapy.J Viral Hepat 2013; 20: 530-535

12. Tandon P, Garcia-Tsao G. Bacterial infections, sepsis, and multiorgan failure in cirrhosis. Semin Liver Dis 2008; 28: 26-42

13. Thalheimer U, Triantos CK, Samonakis DN, Patch D, Burroughs AK. Infection, coagulation, and variceal bleeding in cirrhosis. Gut 2005; 54: 556563
14. Wong F, Bernardi M, Balk R, Christman B, Moreau R, GarciaTsao G, Patch D, Soriano G, Hoefs J, Navasa M. Sepsis in cirrhosis: report on the $7^{\text {th }}$ meeting of the International Ascites Club. Gut 2005; 54: 718-725

15. Pieri G, Agarwal B, Burroughs AK. C-reactive protein and bacterial infection in cirrhosis. Ann Gastroenterol 2014; 27: 113-120

16. Gabay C, Kushner I. Acute-phase proteins and other systemic responses to inflammation. $N$ Engl J Med 1999; 340: 448-454

17. Chenevier-Gobeaux C, Borderie D, Weiss N, Mallet-Coste T, Claessens YE. Presepsin (sCD14ST), an innate immune response marker in sepsis. Clin Chim Acta 2015; 450: 97-103

18. Dupuy AM, Philippart F, Péan Y, Lasocki S, Charles PE, Chalumeau M, Claessens YE, Quenot JP, Guen CG, Ruiz S, Luyt CE, Roche N, Stahl JP, Bedos JP, Pugin J, Gauzit R, Misset B, BrunBuisson C. Role of biomarkers in the management of antibiotic therapy: an expert panel review: I currently available biomarkers for clinical use in acute infections. Ann Intensive Care 2013; 3: 22

19. Tong X, Cao Y, Yu M, Han C. Presepsin as a diagnostic marker for sepsis: evidence from a bivariate meta-analysis. Ther Clin Risk Manag 2015; 11: 1027-1033

20. Wu J, Hu L, Zhang G, Wu F, He T. Accuracy of Presepsin in Sepsis Diagnosis: A Systematic Review and Meta-Analysis. PLoS One 2015; 10: e0133057

21. Jiang S, Park DW, Tadie JM, Gregoire M, Deshane J, Pittet JF, et al. Human resistin promotes neutrophil pro-inflammatory activation, neutrophil extra-cellular trap formation, and increases severity of acute lung injury. J Immunol 2014; 192:4795-803.

22. Macdonald SP, Stone SF, Neil CL, van Eeden PE, Fatovich DM, Arendts G, et al. Sustained elevation of resistin, NGAL and IL-8 are associated with severe sep-sis/septic shock in the emergency department. PLoS One 2014; 9:e110678.

23. Yagmur E, Trautwein C, Gressner AM, Tacke F. Resistin serum levels areassociated with insulin resistance, disease severity, clinical complications, and prognosis in patients with chronic liver diseases. Am J Gastroenterol 2006; 101: 1244-52. 